\title{
PAYMENT OF MONEY IN LIEU OF THE CRIME OF CORRUPTION IN THE RECOVERY OF ASSETS
}

\author{
Helmi \\ Faculty of Law, Lambung Mangkurat University \\ Jl.Brigjen H.Hasan Basry, Banjarmasin, Indonesia, 70123 \\ Email: helmi.pmih99@gmail.com
}

Submitted : 23/12/2020 Reviewed: 04/08/2021 Accepted:25/09/2021

\begin{abstract}
In terms of sanctions, the Law on the Eradication of Criminal Acts of Corruption adheres to a double track system, in the sense that in addition to criminal sanctions, it also contains civil sanctions, namely additional penalties in the form of payment of replacement money. So that the law enforcement of corruption in addition to being oriented to "follow the suspect" and "follow the money", to recover state financial losses. The purpose of this research is to analyze the criminal urgency of paying replacement money in corruption crimes and to analyze the criteria for corruption crimes that can be imposed with additional criminal sanctions. This legal research is a prescriptive normative legal research, with a law approach and a concept approach, using primary and secondary legal materials. The results of this study, (a). The urgency of imposing a penalty for paying compensation is to recover state financial losses from corruption, in which case corruption involving state finances is an act that robs the community of socio-economic rights as stated in the 1945 Constitution, and the penalty for replacement money that has been paid by the convict can be used to "promote the general welfare". (b). The criteria for imposing a substitute money penalty are: (1). the criminal act of corruption committed by the defendant has caused state financial losses; (2). The defendant has obtained property from the act of corruption he has committed; and (3). The defendant has not returned the state financial loss in the amount of the property he has obtained.
\end{abstract}

Keywords:Asset Recovery; Reimbursement Payment

DOI: 10.32801/lamlaj.v6i2.221

\section{INTRODUCTION}

In Indonesia, corruption is a social phenomenon that gets a lot of attention from various groups. In terms of intensity, corrup- tion in Indonesia is often likened to an iceberg in the middle of the ocean, only a few of which can be seen, namely the peak, while the invisible part is the largest part of reality. 
Its distribution has spread to all government institutions, both the central government and regional governments, both on the executive, legislative and judicial sides, which is known as judicial corruption. Indonesia deserves to be called a "corruption emergency".

Criminal policy in the sense of rational efforts made to tackle corruption, among others with a penal approach. The penal approach has been carried out by making laws and regulations governing corruption as a legal protection, namely Law Number 31 of 1999 as amended by Law Number 20 of 2001. In Law Number 31 of 1999 as amended by Law Number 20 of 2001 , between another, there is an additional penalty in the form of compensation money as stated in Article 18. Article 18 paragraph (1) b states: "payment of compensation money in the maximum amount equal to the property obtained from the criminal act of corruption". Furthermore, Article 18 paragraph (2) states: "If the convict does not pay the replacement money as referred to in paragraph (1) letter b no later than 1 (one) month after the court's decision that has obtained permanent legal force, his assets can be confiscated by the court. Prosecutors and auctioned off to cover the replacement money". Paragraph (3) states: "In the event that the convict does not have sufficient assets to pay the replacement money as referred to in paragraph (1) letter $b$, then he shall be sentenced to imprisonment for a length of time that does not exceed the maximum threat of the principal punishment in accordance with the provisions of this Law. This law and the length of the sentence has been determined in a court decision.

Legal sanctions in the form of additional criminal payments of replacement money are basically civil sanctions, namely compensa- tion for criminal acts of corruption that have caused state financial losses. So that the Corruption Eradication Act (PTPK) can apply a double track system as a sanction, namely in the form of criminal sanctions and civil sanctions. Where this system is not found in other criminal laws. So that this is one of the advantages contained in the PTPK Law, even this can be used as an excuse by criminal law enforcers (Police, Prosecutors, Corruption Eradication Commission, and Courts) to be able to optimally use the provisions of the PTPK Law against perpetrators of criminal acts that cause harm. Even though the crime already has its own rules. The formulation of the problem studied is as follows: What is the urgency of the criminal payment of replacement money in criminal acts of corruption; and what are the criteria for criminal acts of corruption for which additional criminal sanctions can be imposed? Thus, the purpose of the study is to examine the urgency of the criminal payment of compensation in the criminal act of corruption; and reviewing the criteria for criminal acts of corruption for which additional criminal sanctions may be imposed.

\section{METHOD}

1. Types of Research

To answer the legal issues that have been formulated, legal research is carried out. Which is a process to find the rule of law, legal principles, and legal doctrines in order to answer the legal issues face. ${ }^{1}$ So that the object (research material) is legal material or library material. So that the research to be carried out includes normative or doctrinal legal research.

2. Research approach

\footnotetext{
1 Peter Mahmud Marzuki, Penelitian Hukum, Cetakan VI. (Jakarta: Prenada Media Group, 2011), 35
} 
In this study, two approaches will be used, namely: (a). The statute approach is carried out because the research plan will explore and find the ontological basis and the legal ratio for the regulation of asset seizure in the Corruption Eradication Act, (b). Concept approach, which is an approach that moves from the views and doctrines that develop in the science of law.

3. Source of legal material

Legal material is the object of study in this research, which consists of primary legal materials and secondary legal materials. The primary legal materials studied are in the form of laws and regulations containing criminal acts of corruption and related laws and regulations, namely:

a. Law Number 8 of 1981 concerning the Criminal Procedure Code, State Gazette of 1981 Number 76;

b. Law Number 31 of 1999 concerning Eradication of Criminal Acts of Corruption, State Gazette of 1999 Number 140 ;

c. Law Number 20 of 2001 concerning Amendments to Law No. 31 of 1999 concerning Eradication of Corruption Crimes, State Gazette of 2001 Number 134 ;

d. Law Number 7 of 2006 concerning Ratification of the United Nations Convention Against Corruption, 2003, State Gazette of 2006 Number 32;

e. Regulation of the Supreme Court Number 5 of 2014 concerning the Additional Penalty of Substitution in Corruption Crimes.

Secondary legal materials are expert thoughts contained in literature texts, journals, research results both contained in research reports and scientific works such as theses and dissertations, papers, including writings downloaded from the internet.

4. Legal material collection procedures

Legal materials are collected through library research in the library. The collection of primary legal materials is carried out by means of a documentary study, by conducting an inventory and categorization of laws and regulations. The collection of secondary legal materials is carried out through a study of the relevant literature.

Inventory of legal materials uses a card system, in which study points such as understanding (concepts) and expert arguments are recorded on a card to facilitate the processing (description) of research results.

5. Analysis

Analysis of all legal materials is carried out by relying on sentence narratives using normative instruments, both legal dogmatic, legal theories to answer legal problems or legal issues. To the laws and regulations, content analysis is carried out with the method of interpretation of legal science.

\section{ANALYSIS AND DISCUSSION}

The Urgency of Additional Criminal Payment of Substitution in Corruption Crimes

Corruption is not only a problem for a particular country but has become a problem for the world community. In other words, corruption is a trans-national crime. This concern of the world community is reflected in various conventions initiated by the United Nations, which express the concerns of the world community.

Various expressions from the world community against corruption, such as: corruption as a form of crime as business, economic 
crime, white collar crimes, official crime and abuse of power. ${ }^{2}$ The 6 th United Nations Congress 1980 in Caracas Venezuela, categorized corruption as a crime that is difficult to reach by law. Law enforcement officers are relatively powerless to deal with this crime. This is due, firstly: the high economic or political status of their perpetrators (the high economic or political status of their perpetrators), second: the circumstances surrounding the acts they committed are such that they reduce the likelihood of them being reported or prosecuted (the circumstances under which they had been committed were such as to decrease the likelihood of their being reported and prosecuted). ${ }^{3}$

At the General Assembly of the United Nations on December 16, 1996, a resolution on the eradication of corruption was issued, which was stated in the document "United Nations Declaration Against Corruption and Bribery in International Commercial Transactions". In principle, the content of the declaration is that the United Nations calls for attention and encourages member states to take countermeasures, either individually, or through international and regional cooperation, based on the constitution and the principles in their respective legal systems. In order to achieve the effectiveness of law enforcement in overcoming corruption, it is stated, among other things, recommending that member countries can adopt the necessary legal provisions as long as these have not been regulated in their respective legal systems. ${ }^{4}$

\footnotetext{
2 H. Elwi Danil, Korupsi. Konsep, Tindak Pidana, Dan Pemberantasannya (Jakarta: Rajawali Press, 2011), 61.

3 Muladi and Barda Nawawi Arief, Bunga Rampai Hukum Pidana (Bandung: Alumni, 1984)., H.Elwi Danil Ibid, 62

4 Danil, Korupsi. Konsep, Tindak Pidana, Dan Pemberantasannya, 63
}

The United Nations Declaration continued a year later with the signing of the "Declaration of the 8th International Conference Against Corruptions" in Lima Peru. Its contents include a clause that places the obligation for each participating country to increase the effectiveness of laws relating to corruption to the maximum extent possible, while remaining within the corridors of their respective constitutions and norms of universal human rights. ${ }^{5}$

The concern of the international community reached its peak with the declaration of the United Nations Declaration convention Against Corruption (UNCAC), which was ratified at the diplomatic conference in $\mathrm{Me}$ rida Mexico in December 2003. The General Assembly of the United Nations with Resolution No. 57/169 had adopted the draft United Nations Convention as a valid document ready to be signed by the participating countries of the diplomatic conference. In the distribution of the United Nations Convention, it was emphasized that the international community participating in the convention was concerned about the seriousness of the problems and threats posed by corruption to the stability and security of society, which weakened democratic institutions and values, ethics and justice, and jeopardized sustainable development and the rule of law. Therefore, it is necessary to believe in a comprehensive and multidisciplinary approach to prevent and combat corruption effectively. ${ }^{6}$

This is a form of appreciation for the countries participating in the convention for the impact of corruption that causes a sense of concern, and therefore corruption is declared not only a local (national) problem of a coun-

\footnotetext{
5 Ibid, 64.

6 Ibid.
} 
try but has become a problem between countries (transnational).

Corruption is a crime that is classified as an extraordinary crime. Corruption as an extraordinary crime contains an understanding that this crime has a very broad impact, the victims are not individual but collective, causing real victims and potential victims.

The reasons used to categorize corruption as an extraordinary crime are as follows:

a. Because the problem of corruption is deeply entrenched in the life of the nation and state in Indonesia. Corruption is not only detrimental to state finances or the country's economy, but also "destroys" the life of the nation and state, so that this condition has alarmed the international community;

b. Corruption has created poverty and large social inequalities in people's lives, because most people cannot enjoy the rights they should get;

c. Because corruption has experienced very rapid development and growth, the problem is no longer merely a legal problem, but corruption is perceived as a violation of the social and economic rights of the community as part of human rights;

d. Due to discriminatory treatment in law enforcement against perpetrators of criminal acts of corruption;

e. Because corruption is no longer only related to the public sector, but has become a collaboration between the public sector and the private sector. ${ }^{7}$

The term extraordinary crime is also mentioned in the general explanation of Law Number 30 of 2002, that "corruption is a violation of the social rights and economic rights of the community, and because of that,

Ibid, 76-77 corruption is no longer classified as an ordinary crime but has become a crime, be an extraordinary crime." So corruption is to be an extraordinary crime because corruption is a violation of social rights and economic rights of the community, namely the right to obtain a welfare life.

Corruption as one of the extraordinary crimes, the handling of corruption is also carried out in extraordinary ways (exceptional measures) as outlined in extraordinary legal instruments (exceptional instruments). Extraordinary methods mean that there is a deviation from the rules of general criminal law, both regarding the principles of material criminal law and formal criminal law (procedural/procedural law).

The criminal law system in the Criminal Code as a general criminal law rule, allows the holding of exceptional rules as stated in Article 103 of the Criminal Code which states: "The provisions of Chapters I to Chapter VIII Book I also apply to criminal law rules outside the Criminal Code, except for criminal law regulations in the Criminal Code, outside the Criminal Code regulates separately". The provisions of article 103 of the Criminal Code indicate that the Criminal Code is an open codification system, because this rule provides an opportunity for the holding of criminal law rules outside the Criminal Code in accordance with the dynamics and legal needs of the community. It also provides an opportunity for the holding of basic rules of material criminal law which are exceptions to the provisions of the principles of material criminal law that have been regulated in Book I of the Criminal Code. Andi Hamzah said that the most important thing to know is the deviations in the law in question from general provisions or principles of criminal law. 
Meanwhile, those who deviate, automatically apply the general provisions of the Criminal Code, based on the adage "lex specialis derogate legi generali". 8

Referring to the "Declaration of the 8th International Conference Again Corruptions" in Lima Peru, the contents of which include a clause that places the obligation for each participating country to increase the effectiveness of laws relating to corruption to the maximum extent possible, while staying within the corridors of their respective constitutions and norms of universal human rights, the contents of this clause provide an opportunity for participating countries to be creative in making reliable legal regulations in the context of eradicating corruption. It can even be interpreted that this declaration encourages the creation of legal rules that exclude general legal rules, with the limitation that they must pay attention to the constitution of each country and universal human rights norms. Thus, the state constitution and universal human rights are limits that should not be violated in the context of making exceptional legal rules.

In the preamble of Law Number 31 of 1999 in letter "a" it is stated: "that the crime of corruption is very detrimental to state finances or the state economy and hinders national development, so it must be eradicated in the context of realizing a just and prosperous society based on Pancasila and the 1945 Constitution". Whereas in letter b it is stated: "that as a result of criminal acts of corruption that have occurred so far in addition to harming state finances and the state economy, it also hinders the growth and continuity of national development which demands high efficiency".

\footnotetext{
8 Andi Hamzah, Pemberantasan Korupsi, Edisi Revi. (Jakarta: Raja Grafindo Persada, 2005), 2
}

In the introduction to the main ideas behind the preparation of the Draft Law on the Eradication of Criminal Acts of Corruption, it is stated:

"At this time corruption is not only considered a problem of a country, but has become a transnational or cross-territorial problem, in addition to being a "core crime" which is a crime that is a principal crime related to other criminal acts. So that at the transnational level, corruption is identified as being able to increase developments such as: environmental destruction, tax irregularities, state financial deficits, crisis of confidence, capital flight, economic crisis, government instability, high cost economy, income disparity, declining investment, slowing growth, disrupting the national budget, undermines democracy based on trust and undermines trust".

The purpose of imposing additional penalties is in the form of payment of replacement money to withdraw property obtained by the "perpetrator" of the criminal act of corruption he has committed. Assets or assets in any form obtained from criminal acts are the result of a criminal act, illegal assets. So that anyone (not just criminals), is not entitled to own or benefit from these assets. This concept is called the term "crime does not pay". Assets resulting from this crime must be sought to be returned to the state through a court decision in criminal justice (follow the money). Efi Laila Kholis said that one way to recover state financial losses as a result of criminal acts of corruption is to provide additional punishment in the form of payment of replacement money, thus providing results in the form of income to the state treasury. ${ }^{9}$ Yunus Husein stated that the

\footnotetext{
${ }^{9}$ Efi Laila Kholil, Pembayaran Uang Pengganti Dalam Perkara Korupsi, Cetakan I. (Jakarta: Solusi
} 
issue of asset recovery must be seen as important as punishing the perpetrators with the strictest laws in eradicating corruption. ${ }^{10}$ The proceeds of crime are something that the perpetrators of crime cannot have continuously, and therefore must be returned to those who are entitled to it. ${ }^{11}$

In the interest of the state, for a criminal act of corruption which, if it has actually caused state financial losses, an effort that is very necessary is to make efforts to restore the state's financial losses. Because corruption causes state financial losses, basically it is a deprivation of the socio-economic rights of the community which is part of the human rights that have been regulated in the 1945 Constitution.

In paragraph 4 of the Preamble to the 1945 Constitution it is stated: "Then from that to form a Government of the State of Indonesia which protects the entire Indonesian nation and the entire homeland of Indonesia and to promote the general welfare".

Several socio-economic rights are regulated in the 1945 Constitution as follows:

1. Article 27 paragraph (2): "Every citizen has the right to work and a decent living for humanity."

2. Article 28C paragraph (2): "Everyone has the right to develop themselves through the fulfillment of their basic needs, the right to education and to benefit from science and technology, arts and culture, in order to improve the quality of their lives

Publishing, 2010), 5

${ }^{10}$ Yunus Husein, "Perampasan Aset Hasil Tindak Pidana Di Indonesia," Jurnal Legislasi Indonesia 7, no. 4 (2010): 574.

${ }^{11}$ Rafki Saputera, "Tantangan Perampasan Aset Tanpa Tuntutan Pidana (Non Conviction Based Asset Forfeiture) Dalam RUU Perampasan Aset Di Indonesia," Jurnal Integritas 3, no. 1 (2017): 117. and for the welfare of mankind".

3. Article $28 \mathrm{H}$ paragraph (1): “ Everyone has the right to live in physical and spiritual prosperity, to have a place to live, and to have a good and healthy living environment and have the right to obtain health services".

4. Article 31 paragraph (1): "Every citizen has the right to education".

5. Article 31 paragraph (2): "Every citizen is obliged to attend basic education and the government is obliged to finance it".

6. Article 31 paragraph (3): “The government seeks and organizes a national education system that increases faith and piety as well as noble character in the context of educating the nation's life as regulated by law".

7. Chapter; 31 paragraph (4): "The state prioritizes the education budget at least $20 \%$ of the state revenue and expenditure budget as well as the regional revenue and expenditure budget to meet the needs of national education".

8. Article 34 paragraph (1): "The poor and abandoned children are cared for by the state.

9. Article 34 paragraph (2): "The state develops a social security system for all people and empowers the weak and incapable in accordance with human dignity".

10. Article 34 paragraph (3): "The state is responsible for providing proper service facilities and public service facilities."

Socio-economic rights are social welfare rights. According to Titon Slamet Kurnia, social welfare rights are used as a synonym for economic, social and cultural rights. ${ }^{12}$

\footnotetext{
${ }^{12}$ Titon Slamet Kurnia, Interpretasi Hak-Hak Manusia Oleh Mahkamah Konstitusi RI, Cetakan I. (Jakarta:
} 
State finances should be used to achieve the greatest prosperity of the people. Muhammad Djafar Saidi stated that state finances are very important to realize the state's tasks which are the responsibility of the government. ${ }^{13}$ Corruption of state finances can cause poverty and large social inequalities in people's lives, because most people are unable to enjoy the rights they should have. However, if state financial losses due to corruption can be withdrawn (recovered) all through the legal mechanism that has been established in Law Number 31 of 1999 as amended by Law Number 20 of 2001 such as the mechanism stated in Article 18 paragraph (1) letter b, then of course losses that previously existed become non-existent because of the payment of replacement money charged to the convict. If it is proven that the elements of a corruption offense, namely Article 2 or Article 3 which the Public Prosecutor is indicted on, then followed by severe punishment even without the success of efforts to restore state financial losses, then the law enforcement efforts will not have maximum meaning for the state.

Law enforcement in the field of corruption must be different from law enforcement in general, especially against corruption that causes state financial losses. Efforts to recover state financial losses must be followed. Therefore, it is very appropriate, in Law Number 31 of 1999 as amended by Law Number 20 of 2001, legal instruments have been provided for efforts to recover state financial losses as a result of criminal acts of corruption as referred to in Article 2 and Article 3. expressis verbis mentions the existence of financial or economic losses of the state. Recovery of

Mandar Maju, 2015), 287.

${ }^{13}$ Muhammad Djafar Saidi, Hukum Keuangan Negara, Cetakan II. (Jakarta: Raja Grafindo, 2013), 9 state financial losses is very important in order to be used as much as possible to promote public welfare in accordance with one of the goals of the Indonesian state. This additional penalty is also expected to have a deterrent effect for perpetrators of corruption, because it can be used as a tool to "impoverish" corruptors. So that the domino effect acts as a general preventive for people who have the potential to commit criminal acts of corruption.

\section{Criteria for Criminal Acts of Corruption that Can Be Imposed Additional criminal money in lieu of criminal acts of corruption that cause state financial losses}

Based on whether or not itharm state finances, corruption can be divided into 2 (two) groups, namely (a). Criminal acts of corruption that cause financial or economic losses to the state as regulated in Articles 2 and 3 of Law no. 31 of 1999 and; (b). Criminal acts of corruption that do not cause financial or economic losses to the state as regulated in Articles 5 to 13 of Law no. 31 of 1999 and Article 12B of Law no. 20 of $2001 .^{14}$

In Law Number 31 of 1999 as amended by Law Number 20 of 2001, criminal sanctions have been stipulated in the form of the main punishment as stated in the provisions of the offense and additional penalties as referred to in Article 18.

Article 17 of Law Number 31 of 199 states: "In addition to being subject to a criminal sentence as referred to in Article 2, Article 3 , Article 5 to Article 14, the defendant may be sentenced to additional punishment as referred to in Article 18".

Article 18 paragraph (1) states:

\footnotetext{
${ }^{14}$ Adami Chazawi, Hukum Materiil Dan Formil Korupsi Di Indonesia, Cetakan II. (Malang: Bayu Media, 2005), 30
} 
"In addition to additional penalties as referred to in the Criminal Code, additional penalties are:

a. confiscation of tangible or intangible movable goods or movable goods used for or obtained from criminal acts of corruption, including the company owned by the convict where the criminal act of corruption was committed, as well as the price of the goods that replace the goods;

b. Payment of replacement money in the maximum amount equal to the property obtained from the criminal act of corruption;

c. Closure of all or part of the company for a maximum period of 1 (one) year;

d. Revocation of all or part of certain rights or elimination of all or part of certain benefits, which have been or may be granted by the Government to convicts".

(2) If the convict does not pay the replacement money as referred to in paragraph (1) letter $b$ at the latest within 1 (one) month after the court's decision which has obtained permanent legal force, his assets may be confiscated by the prosecutor and auctioned off to cover the replacement money. the.

(3) In the event that the convict does not have sufficient assets to pay the replacement money as referred to in paragraph (1) letter b, he shall be sentenced to imprisonment for a length of time that does not exceed the maximum threat of the principal sentence in accordance with the provisions of this Law and the length of time. The crime has been determined in a court decision.

There is no explanation of Article 18 paragraph (1) letter b, so it is not clear the criteria for corruption cases that can be subject to additional penalties in the form of replacement money. However, in the general explanation of Law Number 31 of 1999, among other things, states: "In addition, this law also contains imprisonment for perpetrators of corruption who cannot pay additional penalties in the form of compensation for state losses" (underlined by the author).

In the practice of criminal execution of this replacement money, it is often not in accordance with the rules and objectives of asset recovery. This can be seen, among others, from the research in Banda Aceh conducted by Intan Munirah et al. In its conclusion, it states: "The implementation of criminal compensation for money which is usually more than one month, which is around three months or more, is not in accordance with the provisions of Article 18 paragraph (2) of the Law on the Eradication of Criminal Acts of Corruption, where the payment period exceeds what has been determined., which is only one month, and the mechanism for the payment of criminal compensation for money is done in installments (non-cash)" "15 This is related to the economic inability of the convict to pay the replacement money. As for the subsidiary imprisonment (in lieu of unpaid replacement money, the judge handed down a relatively light sentence. This is as seen in the results of Ade Mahmud's research, that the provisions of Article 18 paragraph (1) letter b provide space for the judge to subsidize the substitute money penalty with a criminal penalty). relatively short prisons.Empirical reality shows that there is a tendency for convicts of corruption to choose to undergo a subsidiary punishment rather than pay compensation because

\footnotetext{
${ }^{15}$ Intan Munirah, Mohd. Din, and Efendi, "Pembayaran Pidana Uang Pengganti Dalam Perkara Korupsi," Kanun: Jurnal Ilmu Hukum 19, no. 2 (2017): 365, http://www.jurnal.unsyiah.ac.id/kanun/article/ view/6627.
} 
the weight of the subsidiary crime is much lighter and quite economical than having to compensate the state so that the state is still economically disadvantaged. ${ }^{16}$

In connection with the unclear criteria for the criminal act of corruption for which additional compensation is imposed, the General Elucidation of Law Number 31 of 1999 as amended by Law Number 20 of 2001, states, among others; "Those who cannot pay the additional penalty in the form of compensation for state losses", it can be said that this additional penalty in the form of replacement money can only be imposed on perpetrators of criminal acts of corruption that cause state financial losses, namely criminal acts of corruption as stipulated in Article 2 and Article 3 Law Number 31 of 1999.

To be able to impose additional penalties in the form of compensation money as referred to in Article 18 paragraph (1) b of Law Number 31 of 1999, a violation of the criminal provisions of Article 2 and Article 3 must result in a concrete loss of state finances (factual loss). This means that the state's financial losses have actually existed and are not just potential state financial losses. The state financial loss is related to the element of committing one's own actions or enriching another person, or enriching a corporation. It is impossible to say that the element of offense "doing an act of enriching oneself or another person or a corporation is fulfilled, if the state's financial loss is only a potential loss (potential loss).

The criminal provisions of Articles 2 and 3 are formal offenses, meaning that the offense

\footnotetext{
${ }^{16}$ Ade Mahmud, "Dinamika Pembayaran Uang Pengganti Dalam Tindak Pidana Korupsi," Jurnal Hukum Mimbar Justitia 3, no. 2 (2017): 154, https:// jurnal.unsur.ac.id/jmj/article/view/216.
}

formulates an act. The act in Article 2 is committing an act of enriching oneself or committing an act of enriching another person or committing an act of enriching a corporation. Meanwhile, the act in Article 3 is to abuse the authority or opportunity or facilities available to him because of his position.

Affirming that Article 2 and Article 3 of Law Number 31 of 1999 are formal offenses, it can be seen from the Elucidation of Article 2 and Article 3 which states: the state economy" indicates that a criminal act of corruption is a formal offense, namely that the existence of a criminal act of corruption is sufficient with the elements of an act that have been formulated not with the emergence of a consequence".

In the general explanation, it is stated: "In this law, the criminal act of corruption is expressly a formal act. This is very important for proof. With the formal formulation adopted in this law, even though the proceeds of corruption have been returned to the state, the perpetrators of criminal acts of corruption are still brought to court and are still being punished."

Furthermore, in the context of the general explanation, Article 4 states: "returning state financial losses does not erase the punishment."

Referring to the general explanation which states, among other things: “... even though the proceeds of corruption have been returned to the state, the perpetrators of corruption are still brought to court and are still being punished". This means that when the perpetrator violates both Article 2 and Article 3, the state's financial losses have factually occurred, but after committing the violation the perpetrator returns the financial loss. So, it is clear that in the context of the general explanation and in the context of Article 4, the state's financial losses do exist factually, no longer in the form 
of potential losses.

The position of Article 2 and Article 3 as formal offenses was finally overturned by the Constitutional Court on January 25, 2017 through its decision Number 25/PUUXIV/2016 stating that the phrase "can" in the formulation of Article 2 and Article 3 of the Anti-Corruption Law is contrary to the constitution so that "not binding" the word "can" makes Article 2 and Article 3 of the PTPK Law a material offense. So that state financial losses must be real (factual loss).

As it has been explained that corruption crimes which mention the existence of "state financial losses", are indeed only stated in Article 2 and Article 3. factually raises state finances. The crime of corruption in question is as referred to in Article 7 and Article 8.

Article 7 paragraph (1) a: "Criminalized with imprisonment of at least two ....: contractor, construction expert who at the time of constructing the building, or seller building materials who, at the time of handing over building materials, commit fraudulent acts that may endanger the security of people or goods, or the safety of the state in a state of war".

Article 8: "Shared with imprisonment for a minimum of 3 (three) years... a civil servant or a person other than a civil servant who is assigned to carry out a general position continuously or temporarily, intentionally embezzles money or securities stored for position, or allow the money or securities to be taken or embezzled by others, or assist in carrying out such acts.

In the context of Article 7 paragraph (1) a, if the procurement of the building is financed from the APBN/APBD, it will inevitably cause state financial losses. Likewise in the context of Article 8, if the embezzled money or securities belongs to the state/region (which is part of state finances), it will also cause state financial losses. It's just that in Article 7 paragraph (1) a and article 8 of the PTPK Law, "state financial loss" is not an element of the offense, while in Article 2 and Article 3 "state financial loss" is an element of the offense.

In the context of additional crime in the form of payment of compensation as referred to in Article 18 paragraph (1) letter b of the PTPK Law, according to the author, it can also be imposed on perpetrators of criminal acts of corruption as referred to in Article 7 paragraph (1) letter a and Article 8, if the actions are factual (real) has caused "state financial losses”. Article 18 paragraph (1) letter $b$ and its explanation do not specifically mention that the application of Article 18 paragraph (1) letter b is only for corruption crimes as referred to in Article 2 and Article 3 , but implicitly applies to corruption crimes that cause "state financial losses". So that an act that meets the offense element of Article 7 paragraph (1) letter a or Article 8 even though it also fulfills Article 2 or Article 3, it is still prosecuted and punished based on the provisions of Article 7 paragraph (1) letter a or Article 8 and is not based on Article 2 or Article 3. This is in accordance with the principle of "Lex specialis derogat lex generalis" (Article 63 to 2 of the Criminal Code) which states: "If an act is included in a general criminal code, it is also regulated in a special criminal rule, then only that particular one is are applied".

The application of additional criminal payments for replacement money is further regulated in Supreme Court Regulation Number 5 of 2014 concerning the Criminal Code of Additional Substitution in Corruption Crimes. In relation to the criminal act of corruption 
which can be imposed on the additional penalty of payment of substitute money,

Article 1 states:

"In determining the amount of payment of replacement money in a criminal act of corruption, it is as much as possible equal to the property obtained from a criminal act of corruption and not merely amount of state financial losses resulting from it".

Article 3 states:

"An additional penalty of replacement money can be imposed on all corruption crimes as regulated in Chapter II of Law Number 31 of 1999 as amended by Law Number 20 of 2001 concerning the Eradication of Corruption Crimes with due regard to Article 1 in above" The explanation of the article:

"In Article 17 of Law Number 31 of 1999 it states that criminal acts of corruption are regulated in Article 2, Article 3, Article 5 to Article 14, apart from being subject to a principal sentence, additional penalties are also regulated in Article 18. Specifically regarding payment of substitute money does not specifically stipulate that this replacement money can only be imposed for violations of Article 2 and Article 3. Thus, in principle, the additional penalty of payment of compensation can be imposed on all corruption crimes as regulated in Chapter II of Law Number 31 of 1999 as amended by Law Number 20 of 2001".

Further explained:

"The imposition of compensation payments for corruption crimes other than those related to state financial losses can be imposed if the defendant's actions obtain the proceeds of corruption while not all the proceeds of corruption can be subject to confiscation based on Article 18 paragraph (1) letter a. As an example in the case of bribery, the property re- ceived by the recipient of a bribe is basically the result of corruption. In principle, these assets must be confiscated into the property of the state. However, it is very possible that the property is no longer in the hands of the defendant, either in whole or in part, so that it cannot be subject to confiscation at the time of investigation and confiscation. In such cases, to prevent the accused from enjoying the proceeds of corruption in the future, the difference in the proceeds of corruption (bribes) which have not been confiscated may be subject to replacement money.

Starting from the provisions of the Regulation of the Supreme Court Number 5 of 2014 in Article 1, Article 3, and their Elucidation, it can be said that the additional punishment is in the form of "payment of replacement money" as referred to in Article 18 paragraph (1) letter b of Law Number 31 of 1999 as amended by Law Number 20 of 2001 can be imposed on all types of corruption crimes as referred to in Chapter II of the Law, provided that the defendant has obtained property from the corruption crime he committed. Even in the explanation, it is stated that the purpose of imposing the additional criminal "payment of replacement money" is "to prevent the defendant from enjoying the results of the corruption in the future". This is actually contrary to the General Elucidation of Law Number 31 of 1999, which states: "In addition, this law also contains imprisonment for perpetrators of corruption who cannot pay additional penalties in the form of compensation for state losses". Because in the General Elucidation it is stated "unable to pay additional penalty in the form of money to compensate for state losses", it is very clear that this additional penalty for payment of compensation is imposed on perpetrators of criminal acts of cor- 
ruption that have caused state financial losses. This opinion is also seen from the opinion of Nastiti Harajeng Putri in the conclusion of her research stating: "The purpose of punishment in eradicating corruption as regulated in the Corruption Eradication Law in addition to causing a deterrent effect, is also to recover state financial losses arising from corruption. To recover the state's financial losses, the Corruption Eradication Law has provided a criminal instrument in the form of Compensation Payments". ${ }^{17}$ As the researcher has stated, corruption that causes state financial losses is not only limited to corruption as referred to in Article 2 and Article 3 of Law Number 31 of 1999 as amended by Law Number 20 of 2001, but also other corruption crimes which even though do not mention state financial losses in the construction of the offense but in fact have caused state financial losses such as Article 7 paragraph (1) letter a and Article 8 of Law Number 31 of 1999 as amended by Law Number 20 of 2001. So the provisions of Article 1, Article 3 and their explanation of The Supreme Court Regulation Number 5 of 2014 contradicts Article 18 paragraph (1) letter b of Law Number 31 of 1999 as amended by Law Number 20 of 2001.

Article 11 paragraph (4) of the Supreme Court Regulation Number 5 of 2014 states: "If the convict pays part of the substitute sentence imposed on him, the payment of the replacement money is calculated proportionally as a reduction in the length of the substitute prison sentence that the convict must serve". This means that this provision makes

\footnotetext{
${ }^{17}$ Nastiti Rahajeng Putri, "Penjatuhan Pidana Uang Pengganti Sebagai Pidana Tambahan Dalam Perkara Tindak Pidana Korupsi," Jurnal Ilmiah: Galuh Justisi 6, no. 1 (2018): 50, https://jurnal.unigal.ac.id/index. php/galuhjustisi/article/view/1239.
}

it possible to change a verdict that has permanent legal force, because in the verdict it has been stated that a substitute prison sentence if the convict does not have sufficient assets to be confiscated. This is based on Article 18 paragraph (3) of Law Number 31 of 1999 as amended by Law Number 20 of 2001 which states: "In the event that the convict does not have sufficient assets to pay the replacement money as referred to in paragraph (1) letter b, shall be sentenced to imprisonment for a length of time that does not exceed the maximum threat of the principal sentence in accordance with the provisions of this Law and the length of the sentence has been determined in a court decision. This means that Article 11 paragraph (1) of the Supreme Court Regulation Number 5 of 2014 contradicts Article 18 paragraph (3) of Law Number 31 of 1999 as amended by Law Number 20 of 2001 . However, this is a legal breakthrough in the practice of executing decisions which also contain additional criminal imposition in the form of payment of replacement money, when the execution prosecutor does not find the convict's property which is sufficient to be confiscated. So that what is confiscated for auction is as much as found in the tracking for confiscation only, while the shortage is replaced with imprisonment by calculating proportionally. So that the prison sentence in lieu of paying replacement money which is not sufficient in the confiscation, will no longer be as long as it was imposed in the court verdict (the duration will be reduced).

\section{The defendant has obtained the property}

convict who was sentenced to additional punishment in the form of substitute money other than the main crime, is the convict who obtained property from the corruption he 
committed. On the other hand, if the convict does not obtain property from the corruption he has committed, then he is not subject to additional punishment in the form of replacement money, but is only sentenced to the main punishment, namely criminal penalties and fines (violation of Article 2 paragraph (1)) and imprisonment and/or imprisonment. or criminal (a violation of Article 3).

The second criterion as mentioned above is based on the provisions of Article 18 paragraph (2) of Law Number 31 of 1999 which states: "Payment of replacement money in the maximum amount equal to the property obtained from the crime of corruption". (Underline from the author). This means that only for convicts who obtain property (material, whatever their form) from criminal acts of corruption Article 2 or Article 3 and other corruption crimes as long as the corruption crime is factually (real) causing state financial losses, the additional crime in the form of money substitute is dropped. A convict of a criminal act of corruption Article 2 or Article 3, does not have to acquire property. The provision of the offense in Article 2 states: “......, commits an act of enriching oneself, or another person, or a corporation", So it is possible that the perpetrator does not commit an act of enriching himself, but commits an act of enriching another person or commits an act of enriching a corporation. Likewise in the provisions of Article 3, the provisions of the offense state: "with the aim of benefiting oneself, or another person or a corporation....". In this case, the perpetrators may not benefit themselves, but aim to benefit other people or a corporation.

If in the case of a criminal act of corruption there are several people (parties) who obtain property, then in a court decision the replacement money is charged proportionally according to the amount of property obtained by each person (party). In other words, the additional penalty for paying this replacement money is not imposed jointly and severally.

\section{The defendant has not returned the state fi- nancial losses in accordance with what was obtained}

If the perpetrator (defendant) of the criminal act of corruption Article 2 or Article 3 obtains property, and the perpetrator has not returned the state financial loss in accordance with the amount of property he has obtained, then the additional penalty for paying the replacement money is imposed on him in a court verdict. Conversely, if the person concerned has returned the property obtained from the criminal act of corruption, both before the legal process and during the legal process (but the refund of the financial loss before there is a court decision that has permanent legal force, then the person concerned cannot be imposed. additional punishment in the form of substitute money as referred to in Article 18 paragraph (2) of Law Number 31 of 1999 as amended by Law Number 20 of 2001.

\section{CONCLUSION}

The urgency of imposing additional punishment in the form of "payment of compensation" is a criminal act of corruption, especially the type of crime corruption that causes state financial losses that has violated the socio-economic rights of the community which are part of human rights as regulated in the 1945 Constitution. Additional criminal penalties are imposed in the form of payment of compensation as regulated in Article 18 paragraph (1) letter b of Law Number 31 of 1999 as amended by Law Number 20 of 2001 is one of the efforts to recover state financial 
losses (asset recovery) or recovery of state assets as a result of criminal acts of corruption used to "promote public welfare"; Criteria for criminal acts of corruption in which the perpetrators are subject to additional penalties in the form of payment of replacement money are: first: the criminal act of corruption committed is a criminal act of corruption that has caused state financial losses as referred to in Article 2 and Article 3 of Law Number 31 of 1999 as amended by Law Number 20 of 2001, also against other criminal acts of corruption that factually (real) cause state financial losses, such as corruption in Article 7 paragraph 91) letter a and Article 8. Second: The convict has obtained property from criminal acts of corruption Article 2 and Article 3 and other corruption crimes that factually cause state financial losses. Third: The convict has not returned the property he has obtained in accordance with the amount of property obtained from the criminal act of corruption before a court decision has permanent legal force (in kracht).

\section{Suggestion}

So, that the Public Prosecutors and Judges in demanding and imposing additional criminal penalties for payment of this replacement money are not only against the perpetrators of corruption in Article 2 and Article 3 of Law Number 31 of 1999 as amended by Law Number 20 of 2001, but also against the other perpetrators of corruption which significantly raises the country's financial losses, such as Article 7 (1) letter a or Article 8.

In the formulation of the future it should be emphasized that, convict for compensation to be imposed for other corruption crimes which in fact (real) have caused state financial losses, even though "state financial losses" are not as bestanddeel offenses (explicit elements of offenses).

\section{BIBLIOGRAPHY}

\section{Books}

Chazawi, Adami. Hukum Materiil Dan Formil Korupsi Di Indonesia. Cetakan II. Malang: Bayu Media, 2005.

Danil, H. Elwi. Korupsi. Konsep, Tindak Pidana, Dan Pemberantasannya. Jakarta: Rajawali Press, 2011.

Hamzah, Andi. Pemberantasan Korupsi. Edisi Revi. Jakarta: Raja Grafindo Persada, 2005.

Kholil, Efi Laila. Pembayaran Uang Pengganti Dalam Perkara Korupsi.

Cetakan I. Jakarta: Solusi Publishing, 2010.

Kurnia, Titon Slamet. Interpretasi Hak-Hak Manusia Oleh Mahkamah Konstitusi RI. Cetakan I. Jakarta: Mandar Maju, 2015.

Marzuki, Peter Mahmud. Penelitian Hukum. Cetakan VI. Jakarta: Prenada Media Group, 2011.

Muladi, and Barda Nawawi Arief. Bunga Rampai Hukum Pidana. Bandung: Alumni, 1984.

Saidi, Muhammad Djafar. Hukum Keuangan Negara. Cetakan II. Jakarta: Raja Grafindo, 2013.

\section{Journal}

Husein, Yunus. "Perampasan Aset Hasil Tindak Pidana Di Indonesia." Jurnal Legislasi Indonesia 7, no. 4 (2010): 574.

Mahmud, Ade. "Dinamika Pembayaran Uang Pengganti Dalam Tindak Pidana Korupsi." Jurnal Hukum Mimbar Justitia 3, no. 2 (2017): 154. https://jurnal.unsur.ac.id/jmj/ article/view/216.

Munirah, Intan, Mohd. Din, and Efendi. "Pembayaran Pidana Uang Pengganti 
Dalam Perkara Korupsi." Kanun: Jurnal Ilmu Hukum 19, no. 2 (2017): 365. http:// www.jurnal.unsyiah.ac.id/kanun/article/ view/6627.

Putri, Nastiti Rahajeng. "Penjatuhan Pidana Uang Pengganti Sebagai Pidana Tambahan Dalam Perkara Tindak Pidana Korupsi." Jurnal Ilmiah: Galuh Justisi 6, no. 1 (2018): 50. https://jurnal.unigal.ac.id/ index.php/galuhjustisi/article/view/1239.

Saputera, Rafki. “Tantangan Perampasan Aset Tanpa Tuntutan Pidana (Non Conviction Based Asset Forfeiture) Dalam RUU Perampasan Aset Di Indonesia." Jurnal Integritas 3, no. 1 (2017): 117.

\section{Law and Regulation}

Criminal Code (translation of PAF Lamintang and Djisman Samosir

History of the Establishment of Law No. 31 of 1999 concerning Eradication of Criminal Acts of Corruption

Law No. 8 of 1981 concerning Criminal Procedure Law, LN of 1981 Number 76.

Law No. 31 of 1999 concerning Eradication of Criminal Acts of Corruption, LN of 1999 Number 140
Law No. 20 of 2001 concerning Amendments to Law No. 31 of 1999 concerning the Eradication of Criminal Acts of Corruption, State Law of 2001 Number 134.

Law No. 7 of 2006 concerning Ratification of the United Nations Convention Against Corruption (UNCAC) 2003, LN of 2006 Number 32

United Nations Convention Against Corruption, 2003 in the 58th Session of the General Assembly in New York through Resolution No. 58 /4 October 31, 2003

Supreme Court Regulation (PERMA) No. 5 of 2014 concerning the Additional Penalty for Substitution in Corruption Crimes, 